\title{
INFILTRATION WELLS ALTERNATIVES TO REDUCE WATER PUDDLE IN LOWOKWARU DISTRICT, MALANG CITY
}

\author{
Hirijanto $^{1 *}$, I Wayan Mundra ${ }^{1}$, Bambang Wedyantadji ${ }^{1}$ \\ ${ }^{1}$ Civil Engineering, National Institute of Technology (ITN) Malang, Indonesia
}

*Corresponding Email:janto.hiri22@gmail.com

\begin{abstract}
Surface waters give a plentiful supply of waters ready to be utilized for residence, farmland, fishery, industry, and electric generating machine, and most importantly, to deal with the problem of water scarcity (crisis). Rain is one of the hydrological cycles that help to preserve groundwater (shallow groundwater). During the rainy season, most waters go directly to the river and the sea without processing, creating inundations and flood in some places. Water resources, however, begin to lose their supporting capacity. Water supply is no longer balanced with the demand that starts to bulge up excessively. This disrupted balance is indicated by many critical lands that are less productive and incapable of absorbing waters to the ground. Considering this outline, the implementation of environmentally friendly infiltration wells can be a strategic option to solve the water balance issue. Some alternatives of infiltration wells are proposed as the solution to the problem that this research deals with. It is estimated that these wells can reduce 10\%-15\% of surface runoff rate in Lowokwaru District of Malang City, especially around SoekarnoHatta Street that always leaves massive water puddle, especially during the rainy season. This research gives the relevant institutions and user community information about drainage construction, drainage network, and land use above drainage network. Through this information, it is expected that the follow-up can be given efficiently to produce an optimum and effective drainage network. Community participation, therefore, is needed to maintain the benefits of alternative infiltration wells to ensure their sustainability in the future.
\end{abstract}

Keywords: Infiltration Well, Drainage Channel, Water Puddle

\section{Introduction}

The urban population has grown fast, exceeding structures and infrastructures provided by the urban authority. A critical feature in the urban environment is drainage management. Flood and inundation are problems associated with poor drainage management. It is worsened by the fact that the drainage system in many cities in Indonesia is partially managed and does not immediately solve drainage-related problems [1].

Urban flood is closely related to poor urban drainage. The flood comes because the drainage system cannot contain rain water intensity and because the surface stream is not flowing correctly. Urban drainage system planning is influenced by factors such as water debit increase, the narrowing and shallowing of waterways, reclamation, land subsidence, waste, garbage, and sea tide-ebb [2]. One reason behind urban drainage failure is speedy population growth due to uncontrolled urbanization. Population growth is always followed up by developing urban infrastructures, such as residence, transportation structures, clean water, education, and others.
However, population increase is accompanied by waste pilings, liquid waste, or solid waste (garbage). Drainage is one crucial aspect to support infrastructures in a particular area or region. The flawed drainage system can negatively affect the community, disrupting life activity due to inundation and disturbing health condition of street users and the community around the street [3].

This research aims to examine the existing conditions of the drainage network by understanding the conditions of drainage construction and drainage network in Lowokwaru District, Malang City, especially in SoekarnoHatta Street and surroundings, as shown in Figure 1.

It is expected that the reader of this research can take benefits from the results of research and at least feel informed about the existing conditions of the drainage network, and by that information, immediate action can be taken to manage and maintain the structures and infrastructures of drainage to minimize and eliminate inundations 


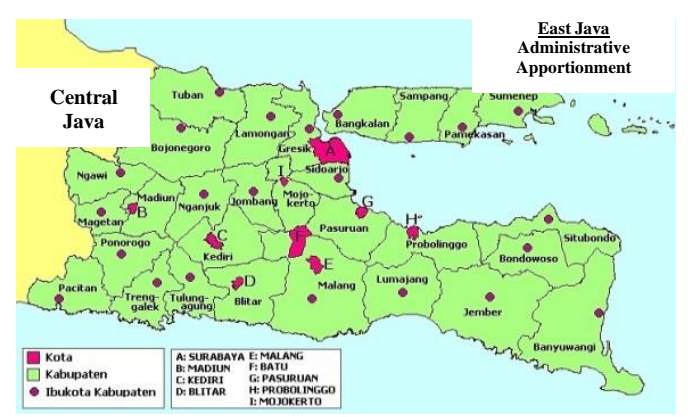

Figure 1 Research Object Location

\section{Literatures Review}

\subsection{Drainage System}

English dictionary associates "drainage" with several verbs such as depleting, disposed, or flowing water away. This research defines drainage as a set of water constructions built by intention to reduce or discard the water excess derived from rainwater, seepage, and irrigation water runoff to preserve optimum use of the land passed by the water stream. One scholar perceived drainage as an effort to control groundwater quality in terms of salinity to obtain the optimum function of the land $[4,5]$.

\subsection{Hydrology Analysis}

Preparing hydrology data is the early phase of drainage system planning before measuring rain flow debit, dimension of waterways, and the dimension of constructions that support the planned drainage system [6].

\subsection{Planned Debit}

Planned Debit is the size of Debit planned to be occurred at a given period. Planned Debit is calculated using rational equation [7]. This rational equation is written as follows:

Planned Debit : $Q=\lceil\cdot$ B....$A$

Planned Debit : $\mathbf{Q}=\mathbf{0 , 2 7 8}$ C.I.A

Where:

$\mathrm{Q}=$ Planned Debit ( $\mathrm{m}^{3} /$ second $)$

$\oint=$ Coefficient of water stream

$\mathrm{B}=$ Coefficient of rain distribution

$\mathrm{C}=$ Coefficient of runoff (dimensionless)

I = Rain intensity during concentration time (mm/hour)

A $=$ Catchman Area (stream area extent)

\subsection{Hydraulic Analysis}

Hydraulic analysis is aimed to determine hydraulic dimensions of drainage channels and its supporting constructions by taking into account planning criteria and hydraulic norms [8].

\subsection{Environmentally Friendly Drainage System Plan}

\subsubsection{Infiltration Well}

Infiltration wells represent one water conservation engineering in the form of construction that is made in such that it resembles dug wells with a certain height (depth), which is to have functioned as to contain rainwater fell from house roof or watertight section at the house, and then enable this water pervaded to the ground, as shown in Figure 2.

Infiltration wells also seem to provide extra water artificially by injecting rainwater into the ground. Location target for wells construction is water catchment area in crop cultivation area, residence, office complex, commercial complex, industry, structures and infrastructures of sport, and other public facilities [9].

Infiltration wells have some benefits, which respectively are [10]:

- Reducing surface stream to minimize and prevent flood and inundation.

- Maintaining and increasing groundwatersurface height.

- Minimizing the possibility of erosion and sedimentation.

- Minimizing and preventing the possibility of seawater intrusion to the area nearby the coast.

- Preventing land subsidence.

- Decreasing the concentration of pollution at ground water.

Form and type of infiltration wells can be square or cylinder with different depth (height), and the bottom of the wells must reside above groundwater surface. The following is several types of infiltration wells [10]:

- Wells are prepared without brickwork on the wall, and the bottom is without fillings of split stones and palm fibres (empty).

- Wells are prepared without brickwork on the wall, and the bottom is filled with split stones and palm fibres.

- Wells are prepared with the brickwork on the wall, which involves the combination of earth brick, river stone, or concrete brick, while the bottom can either be filled with split stones and palm fibres or be left empty. 


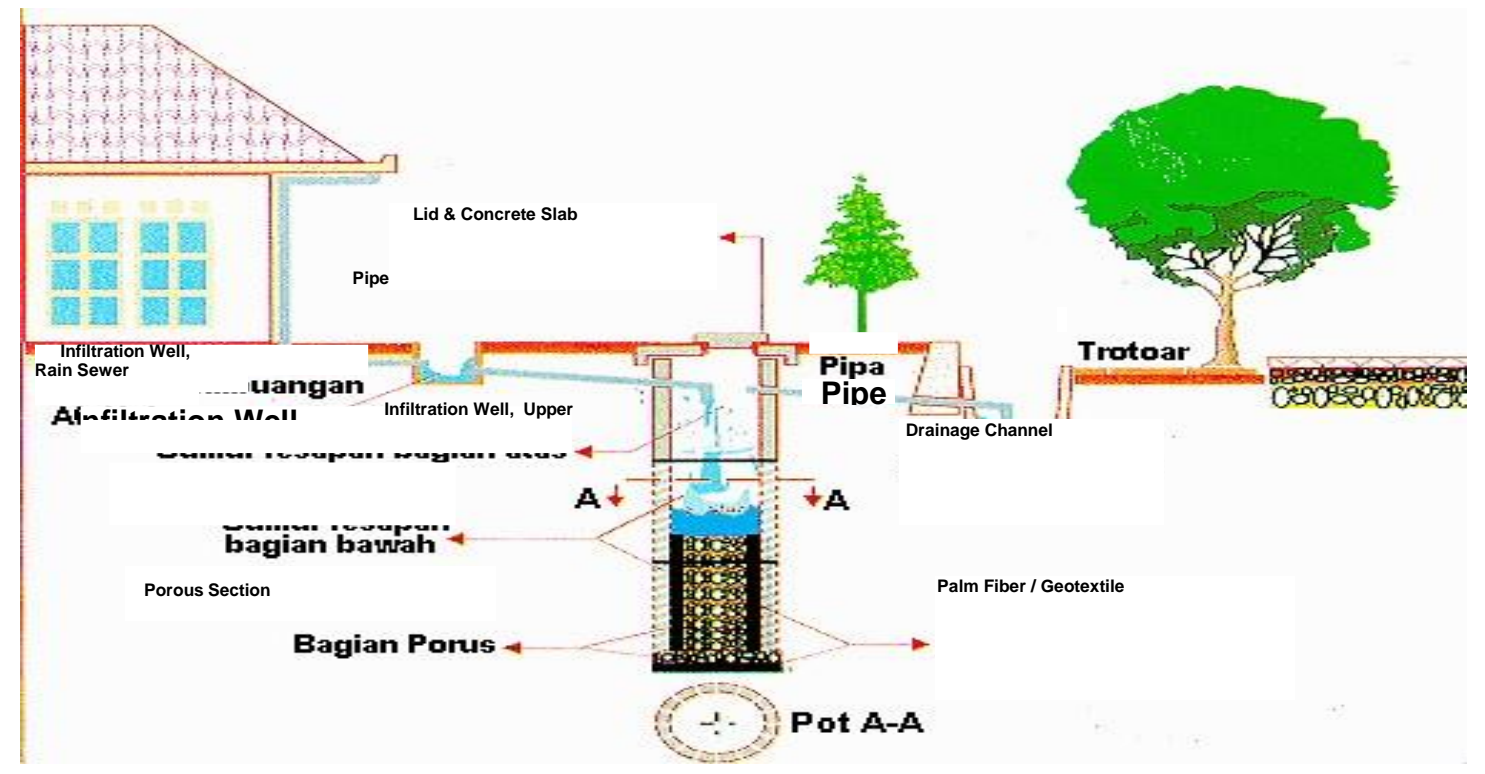

Figure 2 Network Scheme of Household Infiltration Wells

- Wells are prepared by installing concrete bus on the wall.

- Wells are prepared by involving blawong (rocks that are specifically designed to be put on the wall)

All constructions above have strength and weakness. The selection of the best alternative depends on rock and land conditions (precisely, rock formation and land structure) [10].

- If the conditions of rock and land are relatively stable, one of the possible choices is Alternative 1 , which is wells without brickwork on the wall, and the bottom is filled with split stones and palm fibres. This alternative is safe because the filling materials facilitate the infiltration of water through the fissure of the fillings.

- In the same conditions, another choice is Alternative 3, which involves the combination of earth brick, river stone, and concrete brick as materials of brickwork on the wall, and the bottom is filled with split stones and palm fibres. This alternative is considered better than Alternative 1 and even recommended.

- If the conditions of rock and land are volatile (labile), the suggested construction alternative is that involving concrete bus or blawong, although water infiltration only happens at the bottom section.

Other supplement constructions may include control container, lids for infiltration wells and control container, inlet and outlet channels (outlet channel can be open or closed), and roof gutter (only for the house with such component). General Directorate of Work Creation at the Ministry of Public Works and Public Housings has compiled the technical data regarding the recommended infiltration wells. The data are elaborated as follows [10]:

- The maximum diameter of the wells is 1.4 meters.

- The maximum diameter of the inlet pipe is 110 $\mathrm{mm}$.

- The maximum diameter of the outlet pipe is $110 \mathrm{~mm}$.

- Recommended height (depth) is $1.5-3$ meters.

- Wall is upheld with the arrangement of either earth brick or concrete brick, and brick material is prepared with the ratio of 1 for cement and 4 for sand without plaster.

- Cavities in the wells are filled with porous stones 20/20 that form a layer of $40 \mathrm{~cm}$ thickness.

- The lid of infiltration wells may use a concrete slab of $10 \mathrm{~cm}$ thickness, and this slab is prepared with the ratio of 1 for cement, 2 for sand, and 3 for gravel.

Other conditions or requirements for infiltration wells have been elaborated in Indonesia National Standard (SNI) No: 03-24532002 concerning Procedure for the Planning of Infiltration Wells for Rain Water at the House Yard. This Standard provides information about general and technical requirements for planning infiltration wells at the house yard. These requirements explain ground water front boundary, soil permeability value, space between 
buildings, and other features relative to the calculation and determination of infiltration wells for rainwater. Before entering the infiltration well, rainwater is contained in a specific cistern and then infiltrated to the wells [11].

General requirements that must be fulfilled in planning infiltration wells are as follows [12]:

- Infiltration wells must be placed on relatively plain land.

- Rainwater that goes to the wells should be pure or not polluted.

- Determination of wells position must consider the security of nearby buildings.

- Infiltration wells design should comply with local regulation.

- Things beyond the requirements above must be acknowledged by the relevant authority.

\subsubsection{Infiltration Debit of Infiltration Wells}

Some factors are influencing water infiltration, such as geometric factor, Coefficient of soil permeability, and ground waterfront height (depth). Infiltration debit is calculated with a formula that is written as follows [13]:

Qinfiltrate $=$ F.C.H

Where:

$\mathrm{Q}_{\text {infiltrate }}=$ Quantity (Debit) of infiltration ( $\mathrm{m}^{3} /$ second)

$\mathrm{F} \quad=$ Factor of geometry of the waterways per length unit (m)

$\mathrm{C}=$ Coefficient of soil permeability ( $\mathrm{m} / \mathrm{second})$

$\mathrm{H} \quad=$ Height (Depth) of infiltration wells(m) 2.5.3 Water Infiltration Time

The time needed by water to infiltrate the ground is calculated with the following [13]:

Tinfiltrate $=V_{\text {wells }} /$ Qinfiltrate

Where:

$\mathrm{T}_{\text {infiltrate }}=$ Time for water infiltration to the ground (minute)

$\mathrm{V}_{\text {wells }}=$ Volume (Capacity) of infiltration wells $\left(\mathrm{m}^{3}\right)$

Qinfiltrate $_{\text {S }}$ Quantity of infiltration at infiltration wells $\left(\mathrm{m}^{3} /\right.$ second $)$

\subsubsection{Wells Filling Time}

The calculation of time needed to fill the wells (or wells filling time) is almost similar to calculating water infiltration time. The formula is written as follows [12]:
$\mathrm{T}_{\text {filling }}=\mathrm{V}_{\text {wells }} / \mathrm{Q}_{\text {wells }}$

Where:

$\mathrm{T}_{\text {filling }}=$ Time needed to fill the wells (minute)

$\mathrm{V}_{\text {wells }} \quad=$ Volume (Capacity) of infiltration wells $\left(\mathrm{m}^{3}\right)$

$\mathrm{Q}_{\text {wells }}=$ Quantity of filling $\left(\mathrm{m}^{3} /\right.$ second $)$

\section{Research Method}

\subsection{Research Frame}

This research is a follow up of previous research conducted by the researcher. The final result of the current research is a database containing some information. Therefore, it is not surprising if the current database is identical to the previous. Primary and secondary data are obtained through interview and data request to the relevant authority. The current research also conducts observation and documentation on drainage construction and drainage network [14].

Drainage planning output was obtained systematically through inventorization activities. Inventorization of drainage network in Malang City has been done for \pm six months. The result of inventorization was technical primarily documents.

Inventorization-related activities are elaborated in sequence order as follows [3]:

1. Preliminary Report Book

Preliminary Report Book is the early phase of inventorization activities. The making of this Book can take time for \pm four weeks. After finishing the Book, the process continues with the discussion of contents in the Book. Some revisions are possibly suggested, and revising the Book is given time for one week.

\section{Data Compilation}

Data and related information are acquired by surveying to collect primary and secondary data in the field. Time allocation for this phase is \pm 4 weeks. Data, facts and information collected are the elements that make up the Book of Fact \& Analysis Report.

3. Data Processing and Analysis

The phase of data processing and analysis takes time for \pm eight weeks. All results of data processing and analysis will be put in the Book of Fact \& Analysis Report.

\section{Plan Drafting}

Plan drafting phase needs time for \pm four weeks. This time allocation is used to analyze the plan draft, present the results of draft analysis, and 
make revisions before stating the final draft in Final Report.

5. Plan Formulation (consulting about substances)

Plan formulation is usually done in a meeting held explicitly for planning. During this meeting, the summary of the plan draft is written in Final Report. Relevant maps (drainage network) in Final Report are possibly changed and perfected. Planner and its associates will escort the verification of the Report's substances, including the acceptance of consent from provincial and ministerial authorities. All processes in this phase are scheduled to be finished in \pm 4 weeks.

\subsection{Flow Chart}

This research involves several paths, and these paths are configured by researcher in a flow chart as follows, as shown in Figure 3.

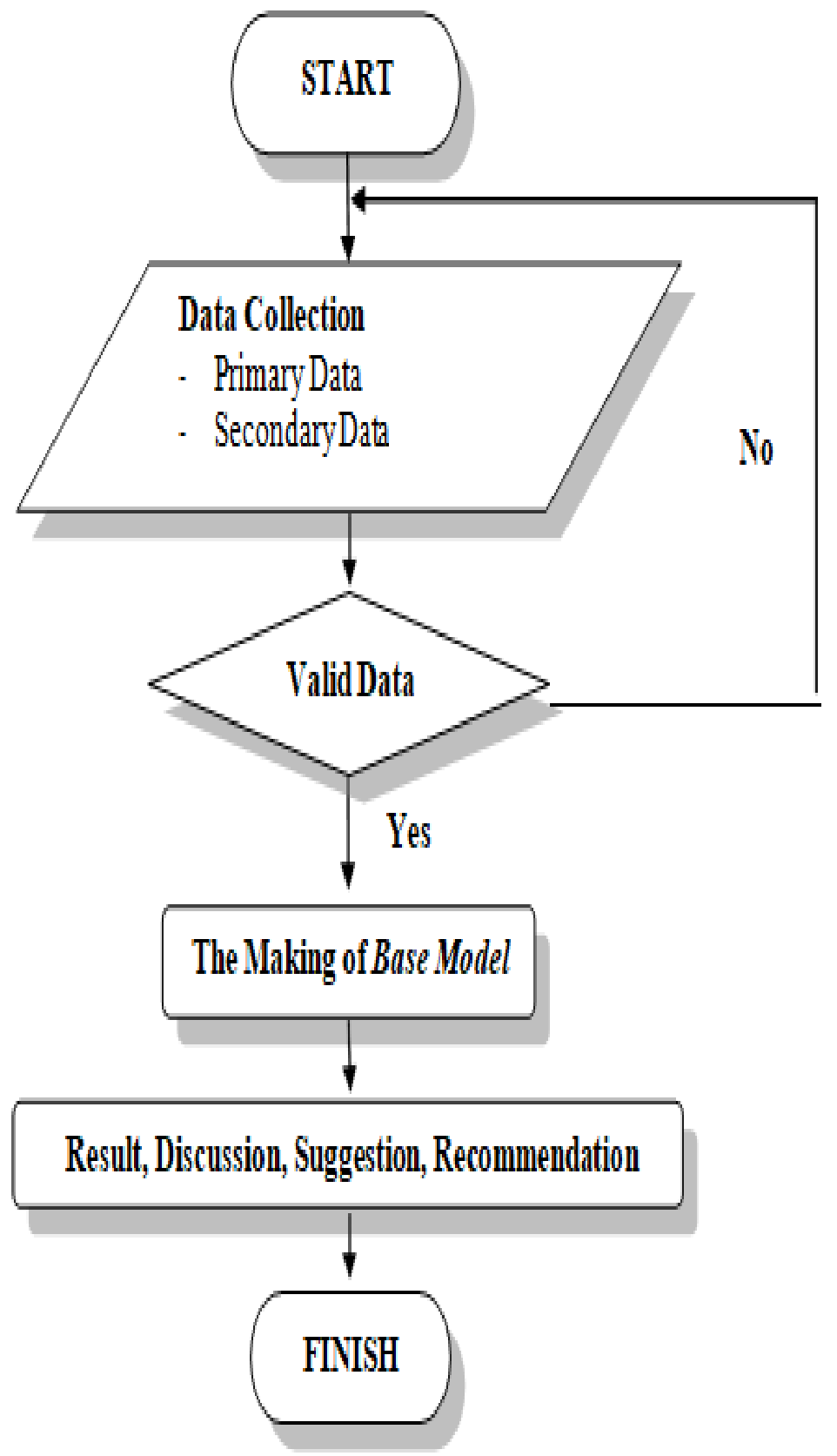

Figure 3 Flow Chart of Research Activities 


\section{Analysis and Discussion}

Table 1 Data and Analysis of Water Channel

\begin{tabular}{lcccc}
\hline \multicolumn{1}{c}{ Name of Street } & \multicolumn{2}{c}{ Elevation } & Channel & Channel Type \\
& Length & & \\
\cline { 2 - 5 } & & & & \\
\hline Puncak Borobudur & & & & \\
\hline Puncak Borobudur & 465.30 & 464.00 & 94.1200 & Tertiary \\
\hline Soekarno Hatta & 465.30 & 464.00 & 95.6500 & Tertiary \\
\hline Soekarno Hatta & 465.30 & 464.00 & 85.7800 & Tertiary \\
\hline Sudimoro & 465.30 & 464.20 & 99.1015 & Tertiary \\
\hline Sudimoro & 465.30 & 464.20 & 99.1629 & Tertiary \\
\hline Sudimoro & 464.00 & 463.40 & 88.5400 & Secondary \\
\hline Sudimoro & 464.00 & 463.40 & 91.3700 & Secondary \\
\hline Ikan Tombro & 462.00 & 461.40 & 56.7657 & Secondary \\
\hline Ikan Tombro & 463.00 & 462.40 & 56.3782 & Secondary \\
\hline Terusan Soekarno Hatta Barat & 463.70 & 463.10 & 64.8153 & Secondary \\
\hline Terusan Soekarno Hatta Barat & 464.70 & 464.10 & 64.2182 & Secondary \\
\hline Borobudur Agung & 464.00 & 463.40 & 86.78 & Primary \\
\hline Borobudur Agung & 464.00 & 463.70 & 44.9467 & Primary \\
\hline Borobudur Agung & 462.20 & 460.00 & 85.64 & Primary \\
\hline & 462.20 & 460.00 & 95.007 & Primary \\
\hline
\end{tabular}

Table 2 Results of analysis on flow debit and planned channel capacity

\begin{tabular}{|c|c|c|c|c|c|}
\hline $\begin{array}{c}\text { Name of } \\
\text { Street }\end{array}$ & $\begin{array}{l}\text { Flow } \\
\text { Debit }\end{array}$ & Q-30\% & Qrt & $\mathrm{Q}+\mathrm{Qrt}=\mathrm{Qt}$ & $\begin{array}{c}\text { B } \\
(\mathrm{m})\end{array}$ \\
\hline
\end{tabular}

\begin{tabular}{lcccccc}
\hline $\begin{array}{l}\text { Puncak } \\
\text { Borobudur }\end{array}$ & 0.04955832 & 0.0148675 & 0.0000000078 & 0.0148675045 & 0.15 & 0.25 \\
\hline $\begin{array}{l}\text { Puncak } \\
\text { Borobudur }\end{array}$ & 0.0439278 & 0.01317834 & 0.0000000101 & 0.0131783513 & 0.16 & 0.2 \\
\hline $\begin{array}{l}\text { Soekarno } \\
\text { Hatta }\end{array}$ & 0.07278878 & 0.02183664 & 0.0000000123 & 0.0218366474 & 0.2 & 0.21 \\
\hline $\begin{array}{l}\text { Soekarno } \\
\text { Hatta }\end{array}$ & 0.06466778 & 0.01940033 & 0.0000000224 & 0.0194003555 & 0.17 & 0.23 \\
\hline Sudimoro & 0.05670022 & 0.01701007 & 0.0000000115 & 0.0170100776 & 0.22 & 0.27 \\
\hline Sudimoro & 0.02263572 & 0.00679072 & 0.0000000023 & 0.0067907192 & 0.31 & 0.4 \\
\hline Sudimoro & 0.15106132 & 0.0453184 & 0.0000000308 & 0.0453184264 & 0.32 & 0.38 \\
\hline Sudimoro & 0.07860284 & 0.02358085 & 0.0000000074 & 0.0235808591 & 0.3 & 0.41 \\
\hline $\begin{array}{l}\text { Ikan } \\
\text { Tombro }\end{array}$ & 0.04938239 & 0.01481472 & 0.0000000085 & 0.0148147241 & 0.33 & 0.43 \\
\hline $\begin{array}{l}\text { Ikan } \\
\text { Tombro }\end{array}$ & 0.06890357 & 0.02067107 & 0.0000000061 & 0.0206710782 & 0.35 & 0.45 \\
\hline $\begin{array}{l}\text { Terusan } \\
\text { Soekarno }\end{array}$ & 0.04042307 & 0.01212692 & 0.0000000056 & 0.0121269275 & 0.38 & 0.47 \\
$\begin{array}{l}\text { Hatta } \\
\text { Barat }\end{array}$ & & & & & & 0.44 \\
\hline Terusan & 0.06461331 & 0.01938399 & 0.0000000130 & 0.0193840065 & 0.45 \\
\hline
\end{tabular}




\begin{tabular}{lcccccc}
\hline $\begin{array}{l}\text { Soekarno } \\
\text { Hatta } \\
\text { Barat }\end{array}$ & & & & & \\
\hline $\begin{array}{l}\text { Borobudur } \\
\text { Agung }\end{array}$ & 0.01810328 & 0.00543098 & 0.0000000016 & 0.0054309853 & 0.43 & 0.5 \\
\hline $\begin{array}{l}\text { Borobudur } \\
\text { Agung }\end{array}$ & 0.0858974 & 0.02576922 & 0.0000000098 & 0.0257692287 & 0.5 & 0.55 \\
\hline $\begin{array}{l}\text { Borobudur } \\
\text { Agung }\end{array}$ & 0.29566517 & 0.08869955 & 0.0000000791 & 0.0886996295 & 0.45 & 0.6 \\
\hline
\end{tabular}

\subsection{Infiltration Wells Design}

The wall of infiltration wells is organized with an arrangement of concrete brick. The finished brick wall must have a diameter of 1.0 and be coated with cement. This coating is done to prevent rainwater from infiltrating the side section (outside the wall) but going directly towards the bottom. Any holes in the wells are left empty to optimize the catchment of rainwater. The bottom section is better filled with 52 split stones that form a layer of $30 \mathrm{~cm}$ thickness. Split stones are a medium to scatter the energy when water enters the wells. Above the layer of stones, palm fibres are arranged as the filter (usually palm fibre of sugar palm $[$ enau $]$ ) that forms a layer of \pm 0.25 meters. These two layers will filter turbid surface water (due to loam content) before the water is infiltrated to the bottom. It is expected that the infiltration process will run smoothly by such a filtration system, as shown in Figure 4.

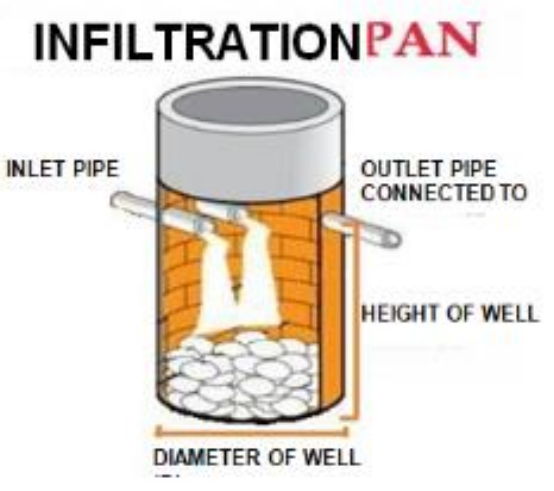

Figure 4 Infiltration Well

\subsection{The Needed Number of Infiltration Wells}

The extent of Lowokwaru District is $20890.500 \mathrm{~m} 2$, and the extent of area covered by watertight buildings is $\pm 16000 \mathrm{~m} 2$. Ground waterfront height is 4 meters. The needed volume of infiltration wells is $4 \%$ of the watertight area, which can be written as: $4 \% \times 16000=6400 \mathrm{~m} 2$, which indicates the total area of infiltration wells. Based on the numbers above, the needed number of infiltration wells can be estimated by dividing the total area of infiltration wells by the needed volume of infiltration wells [15]. It must be noted that infiltration wells height (depth) should not exceed water ground front height. Infiltration Wells Design is $3(\mathrm{~h}) \times 0.5(\mathrm{r}) \times 3.14(\pi)=2.36$ $\mathrm{m} 3$ Total of infiltration wells unit needed in Lowokwaru District is 6400/2.36 = 271.9 $\infty 272$ units of infiltration wells.

\section{Conclusion and Suggestion}

\subsection{Conclusion}

1. The existing waterways and their related calculation do not need redesign except for the damaged waterways and those that need cleaning and normalization of precipitates.

2. The current space order plan has brought along some revisions from the previous plan. Therefore, some outlet waterways are not properly planned. It may hamper the effort to provide the needed number of infiltration wells in Lowokwaru District, which reaches \pm 272 wells units.

3. It is important to socialize with the community concerning the benefits of infiltration wells in reducing water inundations. Although this research finds that infiltration wells only successfully reduce water inundations by around $10 \%$, infiltration wells help preserve ground waterfront height.

4. The area nearby Soekarno-Hatta Roundabout, marked by Airplane Monument, needs special treatment because even the low rain volume can produce inundations. 


\subsection{Suggestion}

The population of Malang City should prepare infiltration wells because these wells give benefits more to vehicle lanes.

1. Additional open space must be provided in Malang City to enable water infiltration and to anticipate extreme weather.

2. Malang City Government should give attention to the Airplane Monument intersection and make a unique plan for this place.

3. Malang City Government must take efforts considered necessary for reforestation in order to affect hydrometeorological weather.

\section{References}

[1] Suripin (2003). Sistem Drainase Perkotaan yang Berkelanjutan. Semarang: Magister Teknik Sipil Program Pascasarjana Universitas Dipenogoro American Assosiation of State Highway and Transportation Officials (1992). Pedoman Drainase Jalan Raya. Jakarta, UI-Press.

[2] Joyce Martha,W. dan Wanny Adidarma, (1982), Mengenal Dasar-dasar Hidrologi, Nova, Bandung.

[3] Sutanto dan Sidharta Karmawan. (2006). Pedoman Drainase Jalan Raya. Penerbit Universitas Indonesia (UI-Press). Jakarta

[4] Ram S. Gupta (1989). Hydrology and Hydraulics Systems. New Jersey: Englewood Cliffs

[5] Suripin (2003). Sistem Drainase Perkotaan yang Berkelanjutan. Semarang: Magister Teknik Sipil Program Pascasarjana Universitas Dipenogoro.

[6] C.D. Soemarto. (1995) Hidrologi Teknik, Jakarta: Erlan

[7] Chow VT. (1988). Applied Hydrology. Singapore: McGraw Hill Book Company.

[8] Triadmodjo Bambang, Dr. Ir. (1993). Hidraulika II. Beta Offset. Yokyakarta

[9] Jayadi, R., (2000). Dasar-dasar hidrologi. Jurusan Teknik Sipil, Fakultas Teknik UGM, Yogyakarta. American Assosiation of State Highway and Transportation Officials (1992). Pedoman Drainase Jalan Raya. Jakarta, UI-Press.

[10] Dewan Standard Nasional -DSN, (SNI - 03 - 3424 - 1994), Tata Cara Perencanaan Drainase Permukaan Jalan, Yayasan Badan Peberbit Pekerjaan Umum, Jakarta.

[11] Imam Subarkah, (1980), Hidrologi Untuk Perencanaan Bangunan Air, Idea Dharma Bandung, Bandung.
[12] Suyono Sosrodarsono dan Kensaku Takeda. (1987). Hidrologi untuk Pengairan. Jakarta: PT. Pradnya Paramita.

[13] Nugroho WS, Rahmad Jayadi (1988). Teknik Drainase. Yogyakarta: Biro Penerbit KMTS FT UGM.

[14] Nugroho Hadisusanto (2010), Aplikasi Hidrologi, Jogja Media Utama.

[15] Mundra, I. W., Hirijanto. (2020). System Dynamics for Simulation Model of Material Cost in Water Resources Project. Journal of Sustainable Technology and Applied Science (JSTAS), 1(2), 25-32. https://doi.org/10.36040/jstas.v1i2.3027 